\title{
25. PALEOMAGNETISM AND TECTONICS OF THE D'ENTRECASTEAUX COLLISION ZONE (SITES 827-831) ${ }^{1}$
}

\author{
Pierrick Roperch, ${ }^{2}$ Xixi Zhao, ${ }^{3}$ and Laura Stokking ${ }^{4}$
}

\begin{abstract}
During Leg 134 of the Ocean Drilling Program 11 holes were drilled at 5 sites to study the process of subduction of oceanic ridges in the d'Entrecasteaux Zone and seamounts beneath the New Hebrides Island Arc. The upper 10 to $100 \mathrm{~m}$ of sediment are composed of volcanic silts characterized by high magnetic susceptibilities $\left(>10^{-2} \mathrm{SI}\right)$. The magnetic susceptibility reflects the amount of volcanogenic materials in the silts. The large differences in magnetic susceptibility between sites suggest that the sediment source is related to the uplift and erosion of Espiritu Santo Island and that currents and topography control the location and rate of sediment deposition as indicated by the very low proportion of volcanogenic sediment on top of the Bougainville Guyot. Only a normal component of magnetization was identified in the volcanic silts indicating deposition of the sediment during the Brunhes Chron. We were unable to determine a magnetostratigraphy in the deformed substratum of the New Hebrides Island Arc (Sites 827, 829, and 830). At Site 828, located on the North d'Entrecasteaux Ridge, pass-through whole-core cryogenic and discrete sample measurements define a straightforward magnetostratigraphy in a 25 -m sequence of nannofossil-chalk sediment below the Pleistocene silts. Correlations with the geomagnetic reversal time scale and biostratigraphic markers indicate that these pelagic sediments were deposited during the Oligocene from 30 to $36 \mathrm{Ma}$. In 35 samples of Oligocene age, a reliable magnetization was observed with a mean inclination of $37.4^{\circ}$. This mean inclination corresponds to a paleolatitude of $20.9^{\circ} \mathrm{S}$, which is about $10^{\circ}$ farther north than the expected latitude based upon the hotspot reconstruction model. Paleocene to Eocene volcanic rocks were recovered at Site 831 below the carbonate cap of the Bougainville Guyot, but the brecciated nature of the volcanic rocks prevented the determination of a paleolatitude.
\end{abstract}

\section{INTRODUCTION}

One of the objectives of Ocean Drillling Program (ODP) Leg 134 was to study the deformation process of the New Hebrides Island Arc in response to the subduction and collision of the North d'Entrecasteaux Ridge (NDR) and Bougainville Guyot (Fig. 1) Three sites $(827,829$, and 830 ) were drilled on the western flank of the New Hebrides Island Arc. These sites lie a few kilometers east of the poorly defined trench that separates the oceanic Australia-India Plate from the arc. Two sites were drilled to better establish the nature of the basement and the paleogeography of the d'Entrecasteaux Zone: Site 828 on the NDR and Site 831 on Bougainville Guyot.

At each site one or two holes were drilled using the advanced hydraulic piston corer (APC). Recovery was good in the upper sedimentary cover, which is composed of Pleistocene volcanic silt. At each site core recovery using the rotary coring system was poor and unconsolidated sediments were strongly disturbed.

The sections obtained at Site 829 show evidence for a complex accretionary sequence, whereas the rock units drilled at Site 827 and 830 may correspond to a deformed arc substratum (Collot, Greene, Stokking, et al., 1992). Drilling at Site 828 provided the best sedimentary sections for magnetostratigraphic purposes. A thin layer of Pliocene unconsolidated foraminiferal ooze separates the Pleistocene volcanic silts that cover the NDR from a sequence of undeformed Oligocene firm ooze on top of the brecciated volcanic basement of the ridge. Unfortunately, drilling deeply into the basement of the ridge was unsuccessful. Bougainville Guyot was drilled at Site 831 where about $700 \mathrm{~m}$ of reef carbonate overlie an andesitic brecciated basement. Very poor core recovery (approximately $1 \%-2 \%$ ) in the car-

\footnotetext{
' Greene, H.G., Collot, J.-Y., Stokking, L.B., et al., 1994. Proc. ODP, Sci. Results, 134: College Station, TX (Ocean Drilling Program).

${ }^{2}$ ORSTOM, BP 48, 06230 Villefranche-sur-Mer, France.

${ }^{3}$ Earth Science Department, U.C. Santa Cruz, CA 95064, U.S.A

${ }^{4}$ ODP, Texas A\&M University, College Station, TX 77845-9547, U.S.A.
}

bonate prevented any paleomagnetic investigations. Although a total of $150 \mathrm{~m}$ of volcanic breccia was drilled, we were not able to produce a reliable magnetostratigraphy.

In this paper we compare the susceptibility records obtained in the Pleistocene sediment at all five sites on the western flank of the arc and we discuss the relative contribution of volcanic silt and ash as determined from the susceptibility data. Reliable paleomagnetic results were obtained from the Oligocene nannofossil-chalk sediment at Site 828 , and the magnetostratigraphic record is compared to the geomagnetic reversal time scale. The paleolatitude determined from the mean inclination observed in Oligocene nannofossil chalk is then compared with the expected paleogeographic position in the hotspot reference frame from Duncan and Richards (1991).

\section{PALEOMAGNETIC MEASUREMENTS}

This paper presents a summary of the shipboard paleomagnetic data and additional onshore studies of discrete paleomagnetic samples. The magnetic susceptibility was measured using the automated shipboard Bartington whole-core susceptibility meter (WCS). Data were recorded at 2.5 - or 5 -cm intervals. The shipboard whole-core cryogenic (WCC) magnetometer is designed for paleomagnetic measurements of $1.5-\mathrm{m}$ sections of longitudinally split archive core halves. Measurements were taken at 5- or 10-cm intervals. A three-axis alternating field (AF) demagnetizer is mounted in-line with the magnetometer and $\mathrm{AF}$ demagnetizations were conducted at $\mathrm{AF}$ peak-field intensity of 5 or (usually) $10 \mathrm{mT}$ to reduce the importance of secondary magnetizations. Apart from the viscous overprint acquired in the present-day earth magnetic field, a drilling overprint was observed in the Pleistocene volcanic silt (Collot, Greene, Stokking, et al., 1992).

Aboard ship a Molspin spinner magnetometer was used to measure discrete samples (DSS). AF demagnetization was performed using a Schonstedt single-axis AF demagnetizer. Additional measurements of discrete samples were made at the University of California, Santa Cruz, using Schonstedt equipment and at Villefranche-sur-Mer with a Molspin instrument. 


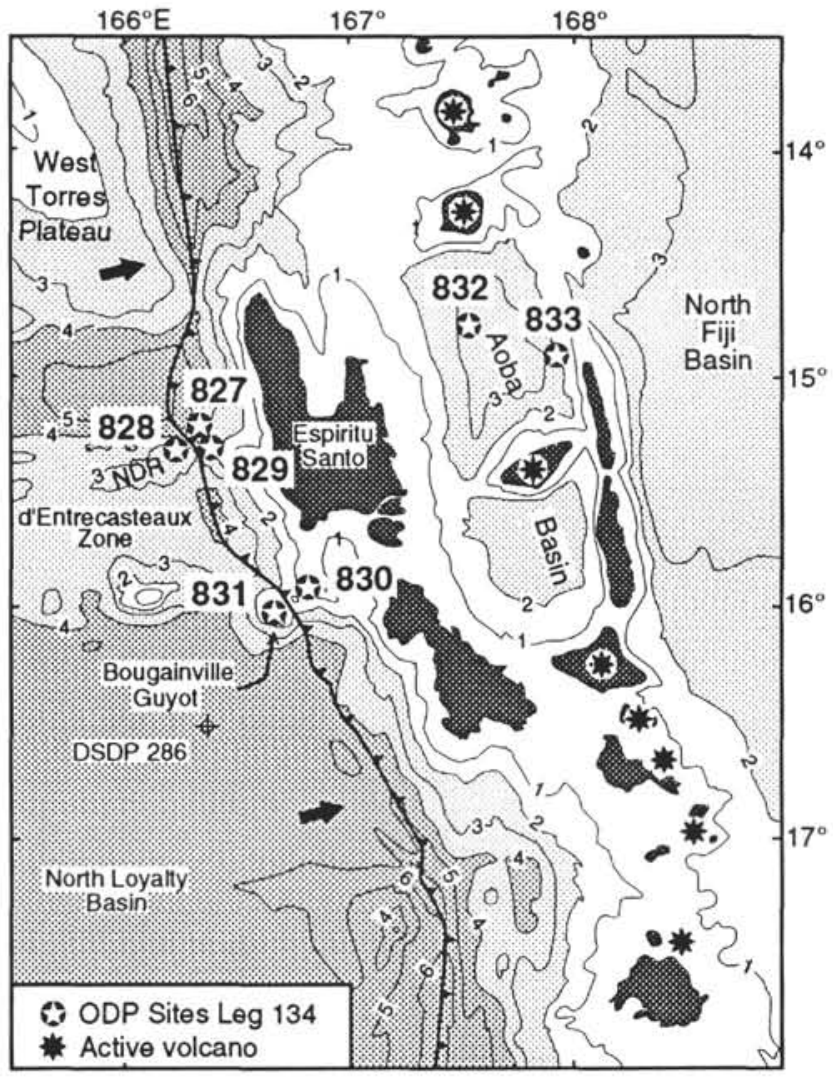

Figure 1. Map of the Central New Hebrides Island Arc showing the location of ODP Leg 134 sites. NDR = North d'Entrecasteaux Ridge.

\section{SUSCEPTIBILITY VARIATIONS IN PLEISTOCENE SILT}

Susceptibility profiles are shown for the upper $60 \mathrm{~m}$ of sediment recovered in APC cores for all sites except Site 829, which was rotary cored (Fig. 2). The magnetic susceptibility is generally high and typical of sediment containing abundant volcanic material. The susceptibility at Site 830 is exceptionally high, reaching 0.1 SI in layers of volcanic sand. However, the susceptibility of the upper sediment on top of the Bougainville Guyot (Site 831) is much lower than at the other sites.

A comparison of the susceptibility data and the density record from measurements with the gamma-ray attenuation porosity evaluator (GRAPE) at Sites 827 and 828 shows a clear correlation between these two physical parameters (Fig. 3). At Site 827, the susceptibility increases slightly downhole with a corresponding increase in density that can be interpreted as the result of compaction. At Site 828 , both susceptibility and density decrease from 10 to 62 meters below sea floor (mbsf) at the transition with the nannofossil ooze. This upward increase of the density and susceptibility correlates with an increase in volcanogenic minerals and opaque minerals as the ridge approached the trench. According to Reid et al., (this volume), hemipelagic sedimentation on the ridge at Site 828 was dominated by deposition of silt-sized volcanoclastic material, which was eroded from the arc and carried offshore in suspension by tidal curents.

The large differences in susceptibility (Fig. 2) between different sites reflect the variation in input of volcanogenic Pleistocene silt from the erosion of nearby islands. Turbidity currents and the topography control the sedimentation. Site 830 is located on the forearc slope in a water depth of about 1000 meters below sea level (mbsl); numerous normally graded interbeds of volcanic black sand with high magnetic susceptibility make up the upper sedimentary sequence. The volumetric importance of sand layers is less at forearc Sites 827 and 829 , which are in greater water depth, at $3000 \mathrm{mbsl}$. Reid et al. (this volume) indicate that the sandy layers have a mean thickness of about $1 \mathrm{~cm}$, which suggests that these sandy layers at Site 827 are distal turbidites. The relative thinness of the sandy layers at Site 827 and 829 explains the absence of strong magnetic susceptibility peaks compared to those observed at Site 830. In contrast with the amount of hemipelagic volcanic silts observed at Site 828, the Bougainville Guyot (Site 831) was isolated from hemipelagic sediment sources.

\section{Importance of Ash Layers}

Magnetic susceptibility is often a suitable tool for use in recognizing volcanic ash layers in pelagic sediment. Because of the abundance of magnetic minerals in the volcanic silt formed by the erosion of the volcanic arc, the magnetic susceptibility background in the sediment is high and the signature of ash layers is not as clear as it would be in pelagic sediment. Most of the thin ash layers (usually less than $5 \mathrm{~cm}$ thick) are marked by peaks in magnetic susceptibility. Figure 4 shows three examples of susceptibility profiles across ash layers at Sites 828, 830 , and 831 . At Site 828 in Core $134-828 \mathrm{~A}-7 \mathrm{H}$, the susceptibility background is much lower than in the upper part of the hole and two ash layers were identified in Sections 134-828A-7H-5 and -6. A susceptibility peak also characterizes an ash layer at Site 831. In contrast, a rhyodacite ash is found within a broad susceptibility minimum at Site 830 in Core 134-830A-3H. Sediment reworking, the thinness of the ash layers, and the abundance of volcanic silt make it impossible to correlate the ash layers between sites.

Deep Sea Drilling Program (DSDP) Site 286 was drilled a few tens of kilometers southwest of Bougainville Guyot in a water depth of approximately $4465 \mathrm{~m}$. Glass-shard ash rich in radiolarians and nannofossils were described at DSDP Site 286 (Shipboard Scientific Party, 1975). Unfortunately, no susceptibility data are available from that site and a comparison between the DSDP site and Bougainville Guyot cannot be made. In our interpretation of the susceptibility data, the contribution of volcanic ash layers to the sedimentation is minor relative to the silt. Susceptibility logging in the guyot also suggests the absence of significant ash layers in the Pleistocene reef carbonate (Roperch et al., this volume).

\section{Accretion of Ridge Sediment to the Forearc}

Drilling at Site 829 shows evidence for the accretion of ridge material (Collot, Greene, Stokking, 1992). At a depth of about 50-60 mbsf, foraminiferal ooze similar to that recovered at Site 828 was found. Whether the silts above the ooze were scraped off the ridge or not is not clear. Susceptibility profiles in the rotary drilled cores from Hole $829 \mathrm{~A}$ and in discontinuous APC cores from Holes 829B and $829 \mathrm{C}$ are more comparable to the record at Site 828 than at Site 827. The susceptibility data may indicate that the lower part of the silt above the foraminiferal ooze at Site 829 is material from the ridge.

\section{MAGNETOSTRATIGRAPHY}

We were able to define a reliable magnetostratigraphy for Site 828 only. The upper $60 \mathrm{~m}$ of volcanic silt from Site 828 are of normal polarity suggesting deposition during the Brunhes Chron. From 61 to 69 mbsf, the sediment is mostly composed of unconsolidated oozes. Biostratigraphic data indicate the presence of major unconformities and that sediment below 69.5 mbsf is nannofossil firm ooze of Oligocene age.

Discrete samples were stepwise AF demagnetized, and the characteristic magnetization, identified on orthogonal diagrams (Fig. 5), was determined by a least-squares fit through the origin. Characteristic directions from discrete samples are shown with whole-core 


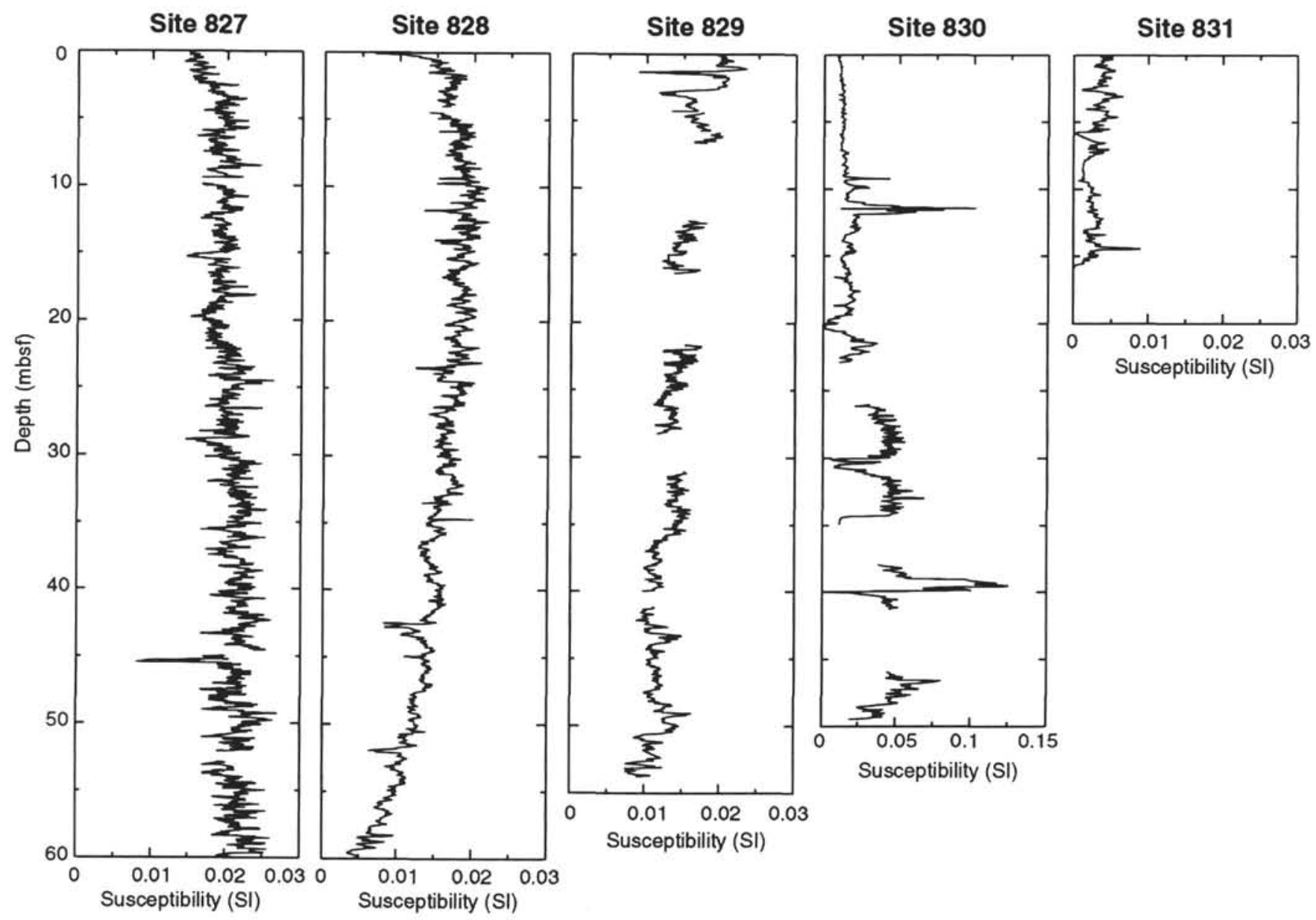

Figure 2. Magnetic susceptibility profiles (SI units) at Sites 827 through 831 . The susceptibility scale is 5 times larger for Site 830 because of the large concentration of magnetite in sandy volcanic sediment.

cryogenic (WCC) results for the depth interval from 69.4 to 89 mbsf in Hole $828 \mathrm{~A}$ (Fig. 6). The consistency between both data sets demonstrates that the secondary magnetization was well removed by $10 \mathrm{mT}$ AF demagnetization in WCC data.

The orientation of the APC cores with the Eastman-Whipstock multishot tool was unsuccessful because the instrument was out of focus. However, each APC core behaves as a single unit and the uncorrected declinations help constrain the interpretation of inclination data. Changes in the sign of the inclination are correlated to $180^{\circ}$ shift in declinations within the same APC core (Fig. 6). In Hole 828A from 89 to $90.7 \mathrm{mbsf}$ the magnetization is unstable in the nannofossil chalk overlaying the volcanic breccia unit.

The first $6 \mathrm{~m}$ of sediment recovered in the first four sections from Core 134-828B-1R, from 90 to 96 mbsf, is nannofossil chalk that recorded only a reversed polarity. Biostratigraphic data (Staerker, this volume) indicates that nannofossil firm ooze recovered in Hole 828B is older than the nannofossil firm ooze deposited above the breccia unit in Hole 828A. Thus, the first $6 \mathrm{~m}$ with reversed polarity should be placed stratigraphically below the nannofossil chalk from Hole $828 \mathrm{~A}$ (Fig. 7). However, this correlation between Holes $828 \mathrm{~A}$ and $828 \mathrm{~B}$ implies a hiatus in Hole $828 \mathrm{~A}$. The paleotopography of the ridge influenced deposition in a manner that produced variable sediment thicknesses (i.e., thicker accumulations in depressions and thinner or no sediment on highs). The correlation of the observed magnetostratigraphy in Hole $828 \mathrm{~A}$ with the geomagnetic reference time scale (Berggren et al., 1985) suggests that the sedimentation rate was low: approximately $20 \mathrm{~m}$ in $3.5 \mathrm{Ma}, 0.6 \mathrm{~cm}$ per $1000 \mathrm{yr}$ (Fig. 7).

\section{PALEOLATITUDE AND TECTONIC IMPLICATIONS}

The most reliable paleomagnetic characteristic directions were found at Site 828. Histograms of inclination values for the Pleistocene volcanic silt and Oligocene nannofossil chalks are shown on Figure 8 . The mean inclinations were calculated using the corrected method of McFadden and Reid (1982).

The drift of Hole 828A was not measured for all cores. Based on the available drift measurements, a value of $3^{\circ}$ toward $100^{\circ} \mathrm{N}$ was used to correct the mean inclination for the volcanic silt and $4^{\circ}$ toward $100^{\circ} \mathrm{N}$ for the bottom part of Hole $828 \mathrm{~A}$. Because of the azimuth of the drift the resulting correction to the mean inclination is less than $1^{\circ}$. The mean inclination for the Pleistocene volcanic silt in Hole 828A $\left(-28.1^{\circ} \pm 3.1^{\circ}\right)$ agrees with the expected inclination $\left(-28.6^{\circ}\right)$ at the present latitude of this site $\left(15^{\circ} 17^{\prime} \mathrm{S}\right)$ in the hypothesis of the geocentric axial dipole field. In contrast, the mean inclination $\left(-37.4^{\circ} \pm 3.5^{\circ}\right)$ observed in the nannofossil chalk is statistically different from the mean inclination measured in the Pleistocene silt. A slightly more southerly latitude $\left(23.4^{\circ} \mathrm{S}<20.9^{\circ} \mathrm{S}<18.6^{\circ} \mathrm{S}\right)$ is indicated by the mean inclination in Oligocene sediment.

No other paleomagnetic results for the region are available to compare with the mean inclination from the NDR. The only significant paleomagnetic data are from the New Hebrides Island Arc (Falvey, 1978), but these data are related to younger geologic units. A few paleomagnetic results on laterites from New Caledonia are reported by Musgrave (1989). Unfortunately, the age of the laterites and the time of acquisition of the remanent magnetization are not 
Hole 827A

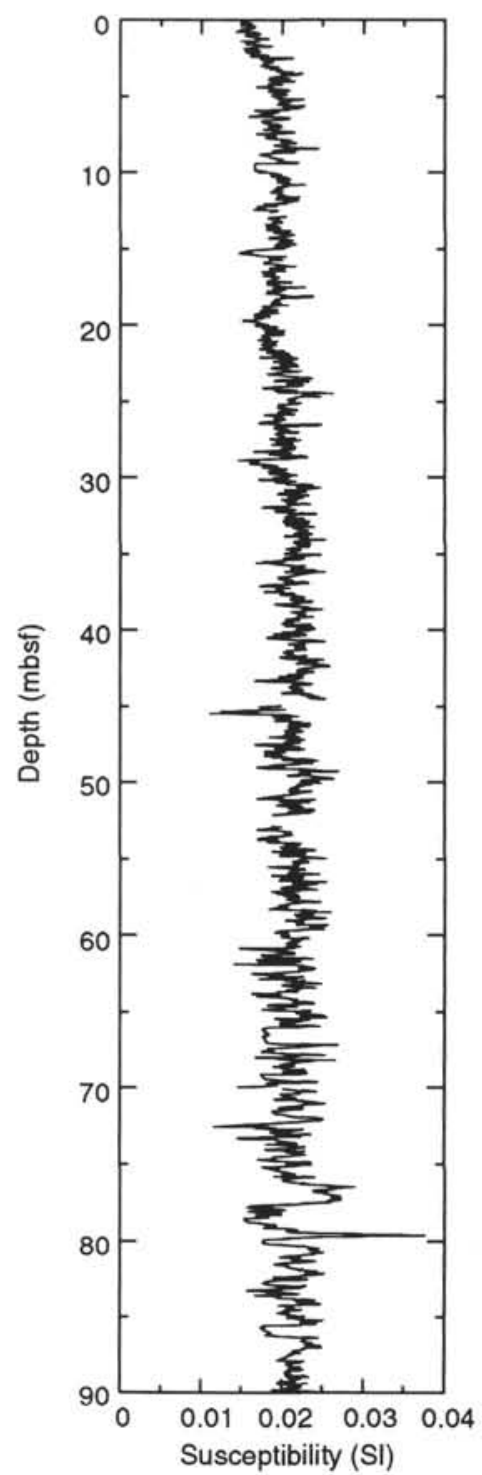

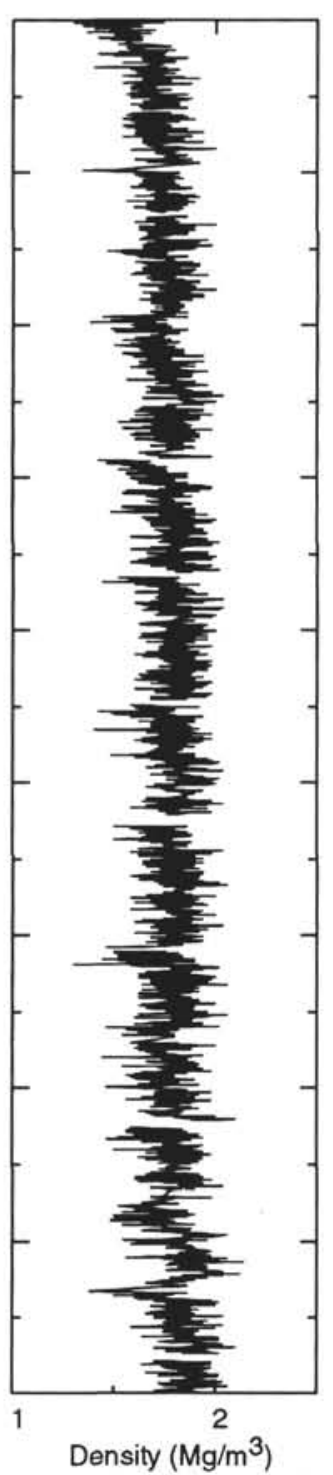

Hole 828A

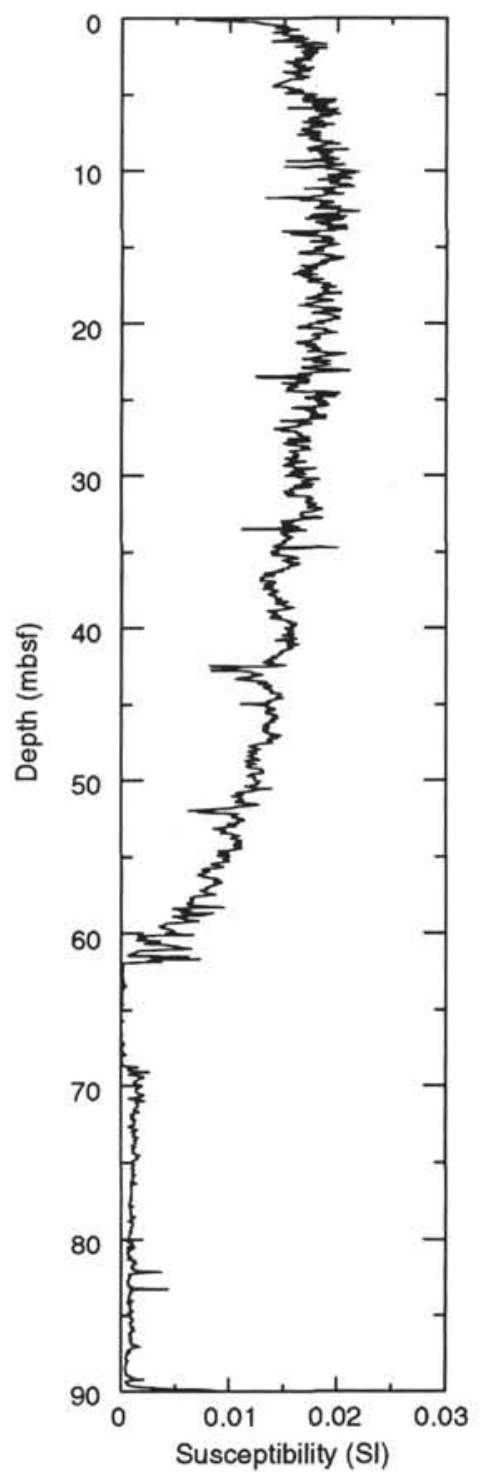

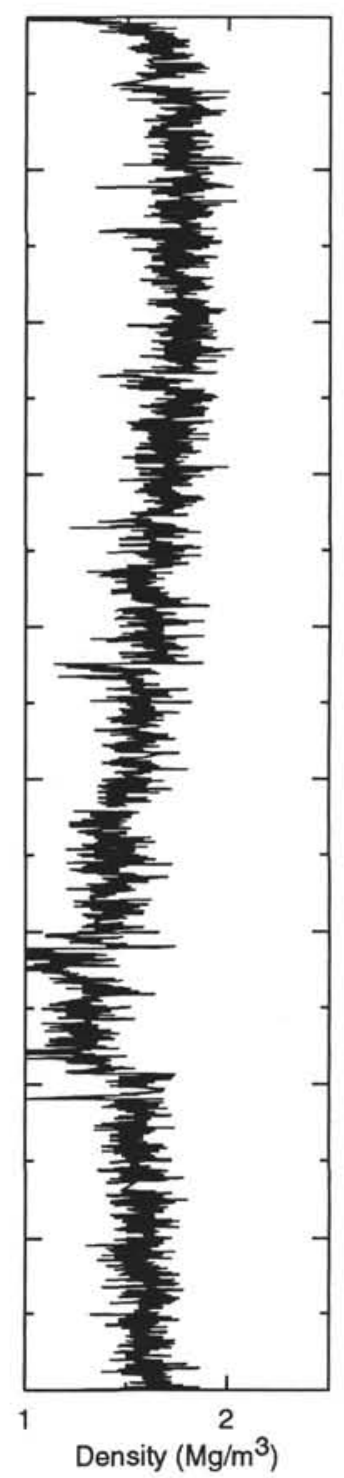

Figure 3. Comparison of the susceptibility profile with the density profile for Holes $827 \mathrm{~A}$ and $828 \mathrm{~A}$. The density profile shows a general decrease at Site 828 caused by the decrease in opaque minerals demonstrated by the decrease in magnetic susceptibility.

independently known. The comparison with the Australian apparent polar wander path (APWP) was used to assign an age to the laterites (Musgrave, 1989).

Plate reconstructions are difficult for the southwest Pacific because of the complex rifting that characterizes the development of the eastern Australian margin and the poorly defined paleoevolution of the western Pacific Plate boundary. Weissel and Watts (1979) showed that spreading ceased in the Tasman and Coral Seas at about $56 \mathrm{Ma}$. Extension in the New Caledonia Basin is thought to have ceased in Paleocene time and obduction of the New Caledonia ophiolite occurred in Eocene time (Collot et al., 1987). Thus, the Coral Sea, the Lord Howe Rise, and New Caledonia Basin have been part of the Australian Plate since early Oligocene. Using the hotspot reference frame of Duncan and Richards (1991), we reconstructed the paleoposition of the southwest Pacific at $36 \mathrm{Ma}$ (Fig. 9). In the hotspot reference frame, the motion of eastern Australia and adjacent basins has been almost strictly north-south with some clockwise rotation since the early Oligocene. If the d'Entrecasteaux Zone formed a continuous homogeneous arc with the New Caledonia Ridge, about $10^{\circ}$ difference exists between the expected latitude based on the hotspot reference frame and the paleolatitude calculated from the mean inclination in Oligocene nannofossil-chalk. Unfortunately, the cores were not successfully oriented; the absence of paleodeclination impedes the observation of post-Oligocene rotations of the d'Entrecasteaux zone.

\section{CONCLUSION}

Magnetic susceptibility records in the upper Pleistocene volcanoclastic sediment have characteristic features depending on the location of the sites, which reflect the origin and the mode of deposition of the hemipelagic sediment. Very high magnetic susceptibility values, up to $0.1 \mathrm{SI}$, are observed in black volcanic sand layers at Site 830 . Only thin sand layers, usually $1 \mathrm{~cm}$ thick, that correspond to distal turbidite deposits, are observed in hemipelagic volcanic sediment at Sites 827,828 , and 829 . This calmer depositional environment at Sites 827,828 , and 829 is reflected by the absence of large susceptibility peaks, in contrast to the record at Site 830 . The amount 

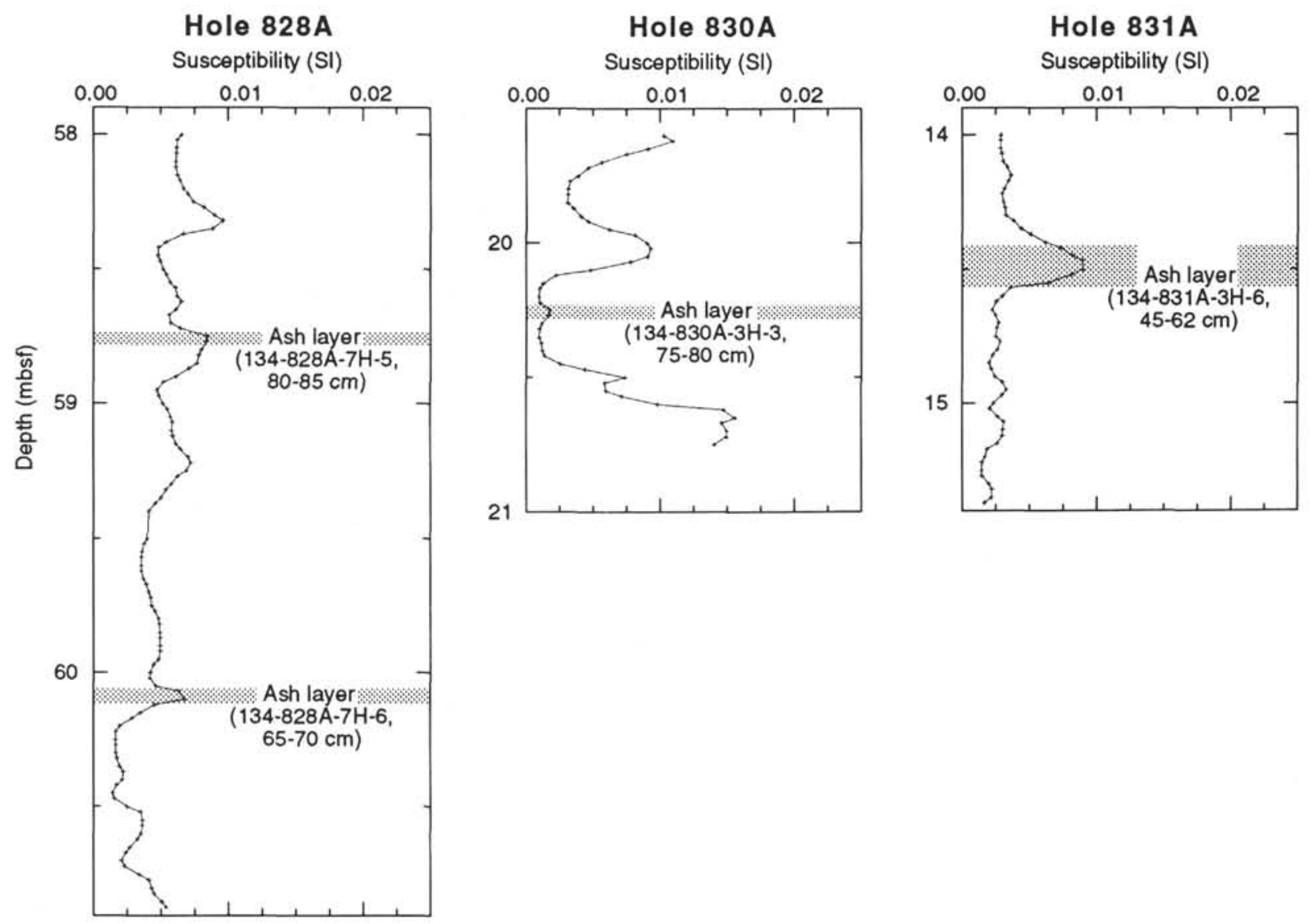

Figure 4. Susceptibility signatures of typical ash layers at Holes 828A, 830A, and 831A.

of volcanic materials in the silt, however, is reflected by low (Site 831 ) and moderate (Site 828 ) to high (Site 827 ) susceptibility values (Fig. 2).

At Site 828, the volcanic silt overlying the Pliocene to Pleistocene foraminiferal ooze records a normal polarity, suggesting that the volcanic silt was deposited only during the Brunhes Chron. The sharp unconformity between the foraminiferal ooze and the hemipelagic silt implies that either the source of the volcanic silt did not exist in the early Pleistocene time (i.e., Espiritu Santo Island was not emergent) or that further away from the arc, currents and topography prevented the deposition of silts on top of the ridge. The interpretation of the magnetostratigraphy in the underlying nannofossil-chalk indicates that the chalk was deposited during Oligocene time from about 35 to $29.5 \mathrm{Ma}$.

The paleolatitude $\left(20.9^{\circ} \pm 2.5^{\circ} \mathrm{S}\right)$ estimated from the mean inclination recorded in Oligocene nannofossil-chalk is different from the one expected (about $32^{\circ} \mathrm{S}$ ) from the hotspot reconstruction model (Duncan and Richards, 1991). The APWP of Australia is poorly defined for the Tertiary but both the APWP of Idnurm (1985) and the most recent Australian APWP from Musgrave (1989) also give a more southerly latitude (about $30^{\circ} \mathrm{S}$ from Idnurm's APWP and $27^{\circ} \mathrm{S}$ from Musgrave's [1989] APWP) than the one determined from the mean inclination at Site 828 . Thus the contributions from the non-dipole field (Schneider and Kent, 1990) and true polar wander (Besse and Courtillot, 1991) cannot explain entirely the discrepancy between the observed paleolatitude and the expected latitude from the hotspot model. Inclination shallowing in deep-sea sediment has been documented in previous DSDP cores. Arason and Levi (1990) reported inclination shallowing up to $6^{\circ}-8^{\circ}$ in Pliocene-Pleistocene DSDP sediment (DSDP Site 578). An increase in inclination shallowing was correlated downhole with a decrease in porosity as a result of com- paction of the sediment. The relation between compaction and porosity due to dewatering is

$$
\Delta \mathrm{V}=\left(\phi_{0}-\phi\right) /(1-\phi),
$$

where $\phi_{0}$ is the initial porosity and $\phi$ is the porosity after compaction (see Arason [1991] for a detailed discussion). The initial porosity in the calcareous sediment is estimated to be $72 \%$ (Hamilton, 1976) and the measured porosity in the nannofossil chalk at Site 828 is about $62 \%$ (index property data Site 828 ; Collot, Greene, Stokking, et al., 1992). Inclination shallowing $(\Delta \mathrm{I})$ can be related to compaction $(\Delta \mathrm{V})$ by an equation of the form

$$
[\tan (\mathrm{I}-\Delta \mathrm{I})=(1-\mathrm{a} \Delta \mathrm{V}) \tan (\mathrm{I})],
$$

(Anson and Kodama, 1987) where $\mathrm{I}$ is the expected inclination and a is a constant that depends on the sediment lithology. Greater shallowing is expected in clayey sediment $(\mathrm{a}=1.1)$ than in calcareous sediment $(\mathrm{a}=0.7)$. The compaction at Site 828 is about 0.26 and inclination shallowing of approximately $6^{\circ}$ can be expected with the hypothesis of a sediment factor $(\mathrm{a}=0.7)$. The observed paleomagnetic inclination $\left(37^{\circ}\right)$ is $14^{\circ}$ steeper than the one implied by the hotspot model $\left(51^{\circ}\right)$ and inclination shallowing cannot account entirely for the observed difference. However, the expected inclination $\left(46^{\circ}\right)$ from the APWP of Musgrave (1989) agrees more with the observed inclination if we take into account a possible shallowing effect $\left(37^{\circ}+6^{\circ}\right.$ $=43^{\circ}$ ). This discussion highlights the difficulty of doing plate reconstruction with the available data. Although a complex tectonic history for the d'Entrecasteaux Zone cannot be ruled out from the available data (i.e., the d'Entrecasteaux Zone was not part of the Australia-India Plate in Oligocene time), more paleomagnetic data are needed to 
establish accurately the paleogeography of the d'Entrecasteaux Zone. A drilling project involving numerous sites with oriented APC cores would certainly highlight the tectonic history of the region.

\section{REFERENCES $*$}

Anson, G.L., and Kodama, K.P., 1987. Compaction-induced shallowing of the post-depositional remanent magnetization in a synthetic sediment. Geophys. J. R. Astron. Soc., 88:673-692.

Arason, P., 1991. Paleomagnetic inclination shallowing in deep-sea sediments [Ph.D. thesis]. Oregon State Univ., Corvallis, Oregon.

Arason, P., and Levi, S., 1990. Compaction and inclination shallowing in deep-sea sediments from the Pacific Ocean. Eos, 71:381.

Berggren, W.A., Kent, D.V., Flynn, J.J., and Van Couvering, J.A., 1985. Cenozoic geochronology. Geol. Soc. Am. Bull., 96:1407-1418.

Besse, J., and Courtillot, V., 1991. Revised and synthetic apparent polar wander paths of African, Eurasian, North American and Indian plates, and true polar wander since $200 \mathrm{Ma}$. J. Geophys. Res., 96:4029-4051.

Collot, J.-Y., Greene, H.G., Stokking, L.B., et al., 1992. Proc. ODP, Init. Repts., 134: College Station, TX (Ocean Drilling Program).

Collot, J.-Y., Malahoff, A., Recy, J., Latham, G., and Missegue, F., 1987. Overthrust emplacement of New Caledonia ophiolite: geophysical evidence. Tectonics, 6:215-232.

Duncan, R.A., and Richards, M.A., 1991. Hotspots, mantle plumes, flood basalts, and true polar wander. Rev. Geophys., 29:31-50.
Falvey, D.A., 1978. Analysis of paleomagnetic data from the New Hebrides. Australas. Soc. Explor. Geophys. Bull., 9:117-123.

Hamilton, E.L., 1976. Variations of density and porosity with depth in deep-sea sediments. J. Sediment. Petrol., 46:280-300.

Idnurm, M., 1985. Late Mesozoic and Cenozoic palaeomagnetism of Australia-I. A redetermined apparent polar wander path. Geophys. J. R. Astron. Soc., 83:399-418.

McFadden, P.L., and Reid, A.B., 1982. Analysis of paleomagnetic inclination data. Geophys. J. R. Astron. Soc., 69:307-319.

Musgrave, R.J., 1989. A weighted least-squares fit of the Australian apparent polar wander path for the last $100 \mathrm{Myr}$. Geophys. J. Int., 96:231-243.

Schneider, D.A., and Kent, D.V., 1990. The time-averaged paleomagnetic field. Rev. Geophys., 28:71-96.

Shipboard Scientific Party, 1975. Site 286. In Andrews, J.E., Packham, G., et al., Init. Repts. DSDP, 30: Washington (U.S. Govt. Printing Office), 69-131.

Weissel, J.K., and Watts, A.B., 1979. Tectonic evolution of the Coral Sea Basin. J. Geophys. Res., 84:4572-4582.

- Abbreviations for names of organizations and publications in ODP reference lists follow the style given in Chemical Abstracts Service Source Index (published by American Chemical Society).

Date of initial receipt: 27 April 1992

Date of acceptance: 16 June 1993

Ms 134SR-024 


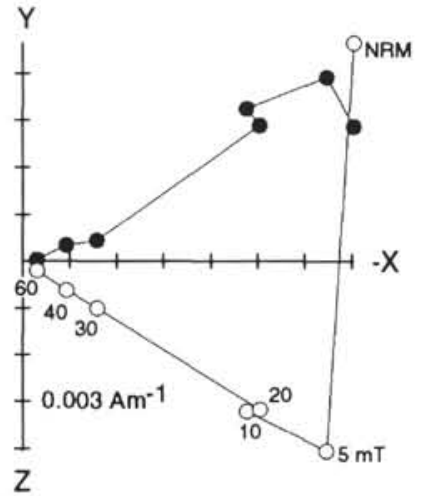

Sample 134-828A-8H-6, $126-128 \mathrm{~cm}$

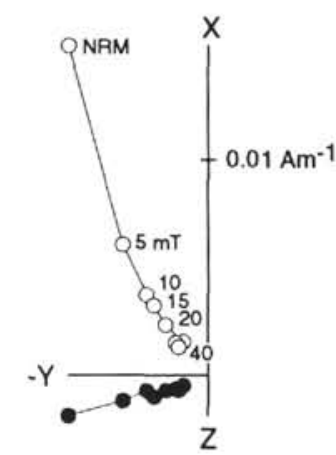
$29-31 \mathrm{~cm}$

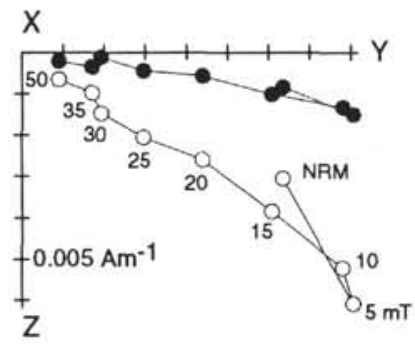

Sample 134-828A-10 H-4, $138-139 \mathrm{~cm}$
Sample 134-828A-9H-7,

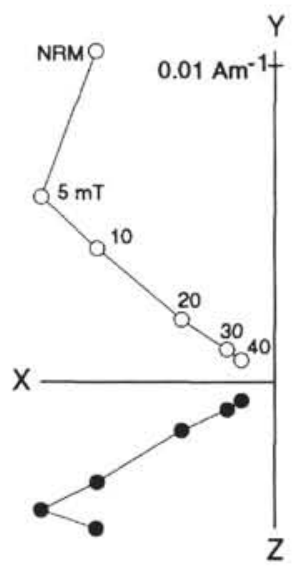

Sample 134-828A-8H-7, $7-9 \mathrm{~cm}$

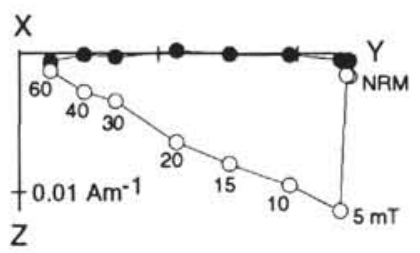

Sample 134-828A-9H-5, $92-94 \mathrm{~cm}$

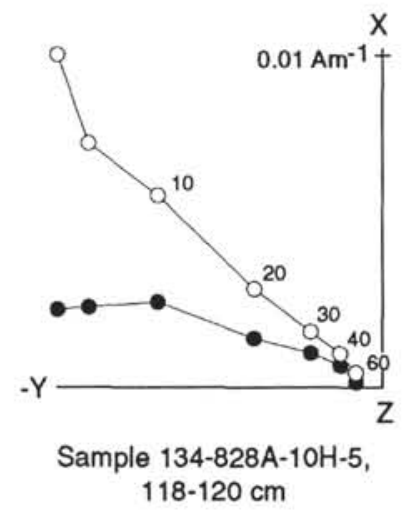

Figure 5. Representative orthogonal AF demagnetization plots of discrete samples in nannofossil sediment from Hole 828A. Open circles represent vector endpoints projected onto the vertical plane; solid circles indicate endpoints projected onto the horizontal plane. $\mathrm{NRM}=$ natural remanent magnetization.

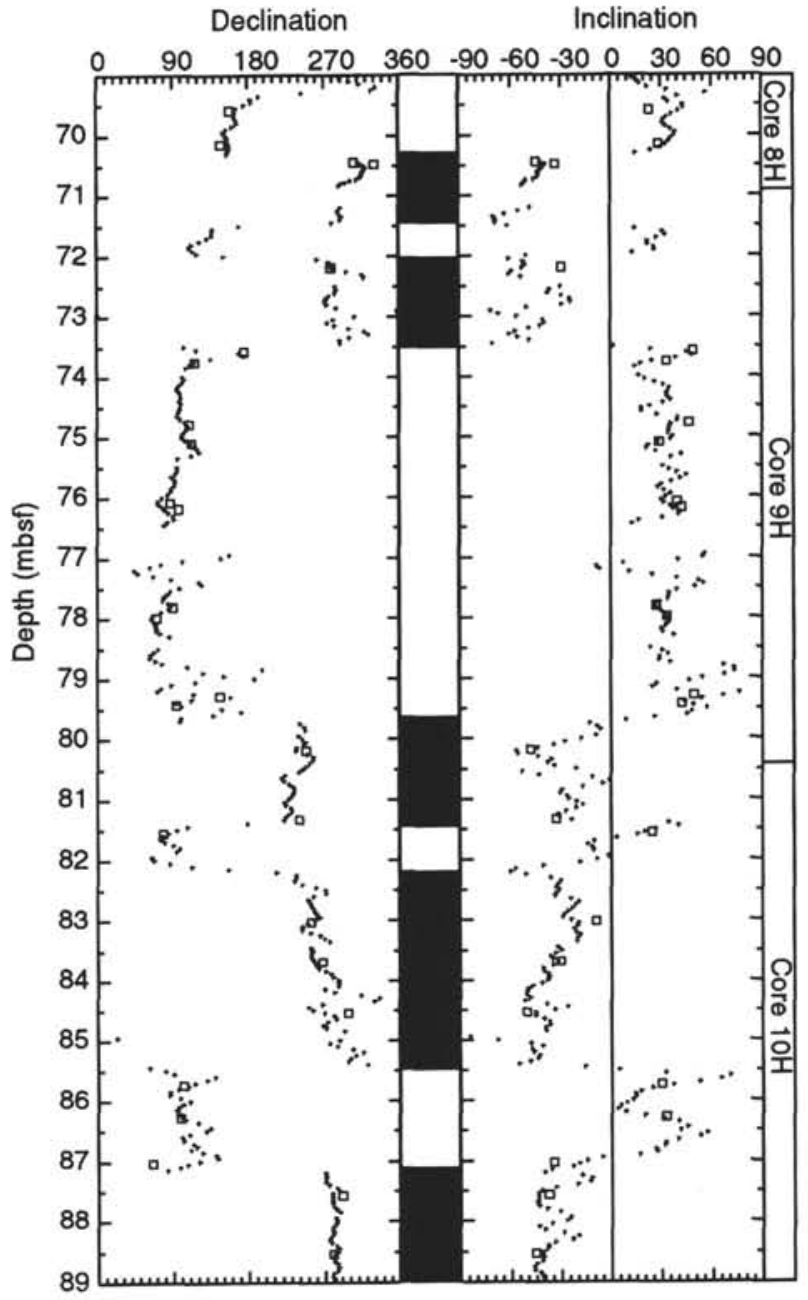

Figure 6. Comparison of pass-through cryogenic measurements (solid marks) with discrete measurements (open squares) from 69 to $89 \mathrm{mbsf}$ in nannofossilchalk sediment from Hole 828A. Changes in inclination are correlated with $180^{\circ}$ shifts in declination that enable a determination of the magnetostratigraphy. 


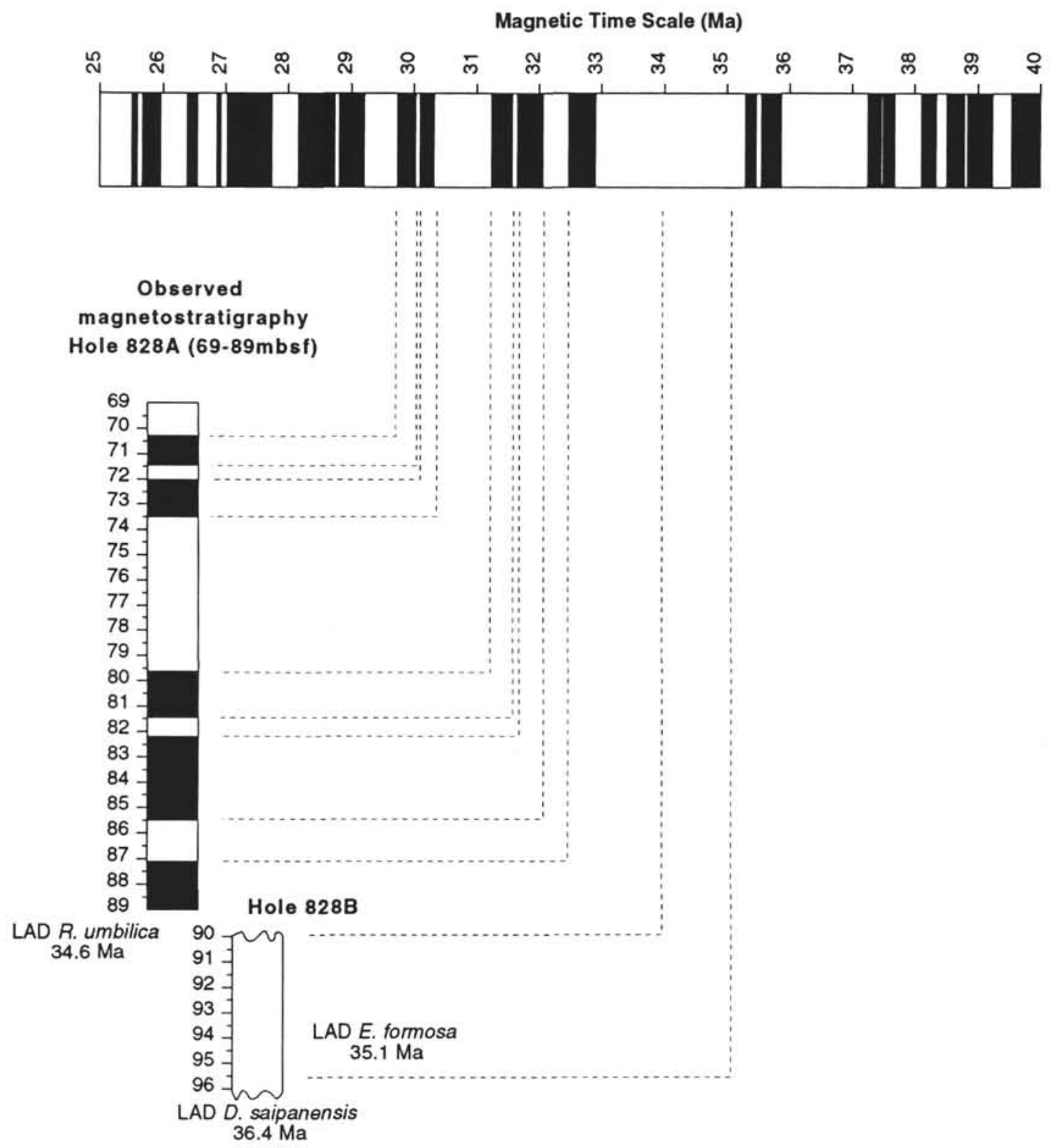

Figure 7. Correlation of the magnetic polarity reversal record for Site 828 with the geomagnetic reversal time scale of Berggren et al. (1985). The key biostratigraphic data from Staerker (this volume) are used to constrain the magnetostratigraphy. LAD = last appearance datum. 

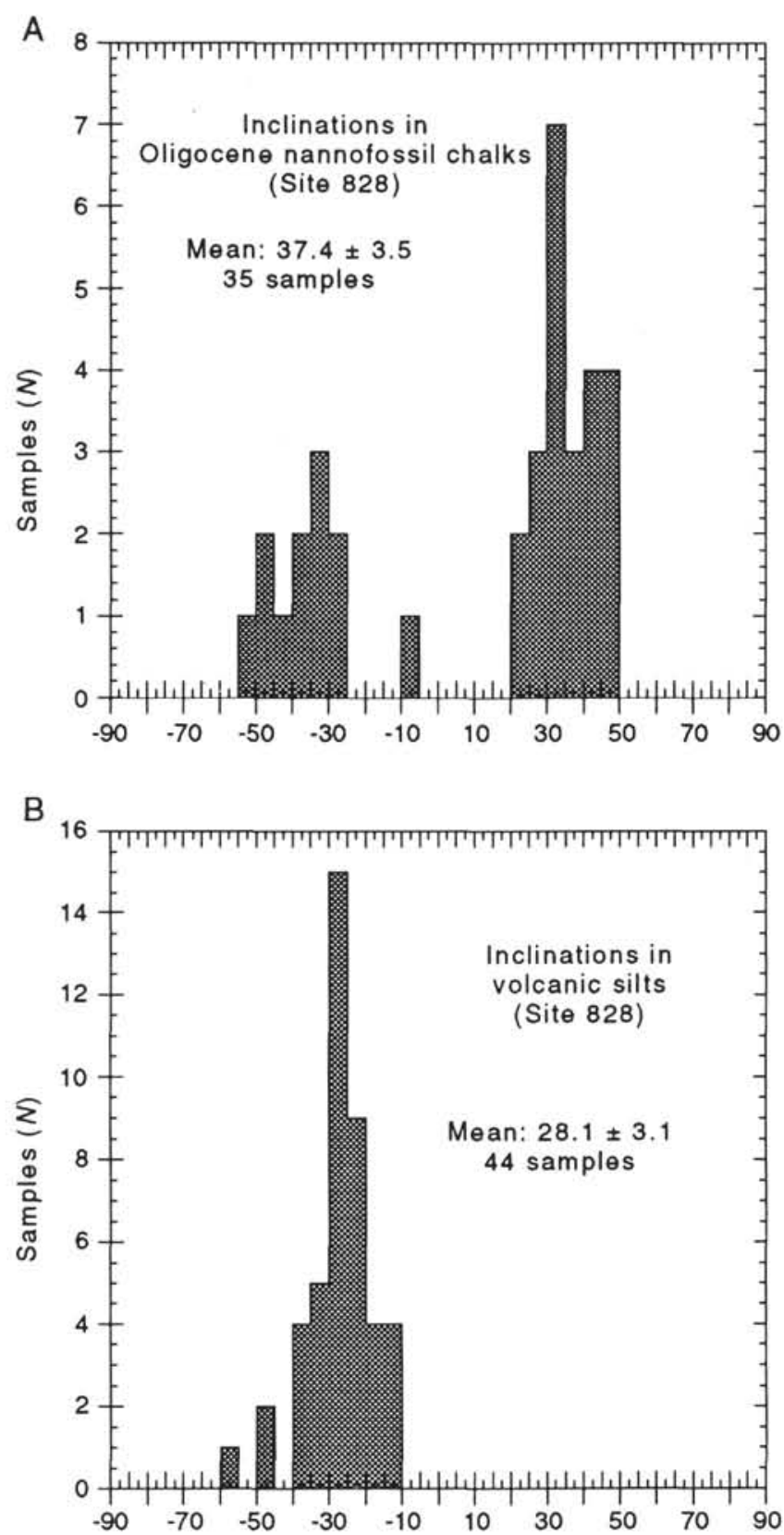

Figure 8. Histograms of characteristic inclinations at Site 828 observed in (A) Oligocene sediment, and (B) Pleistocene silt. The mean inclination was calculated by the method of McFadden and Reid (1982). 


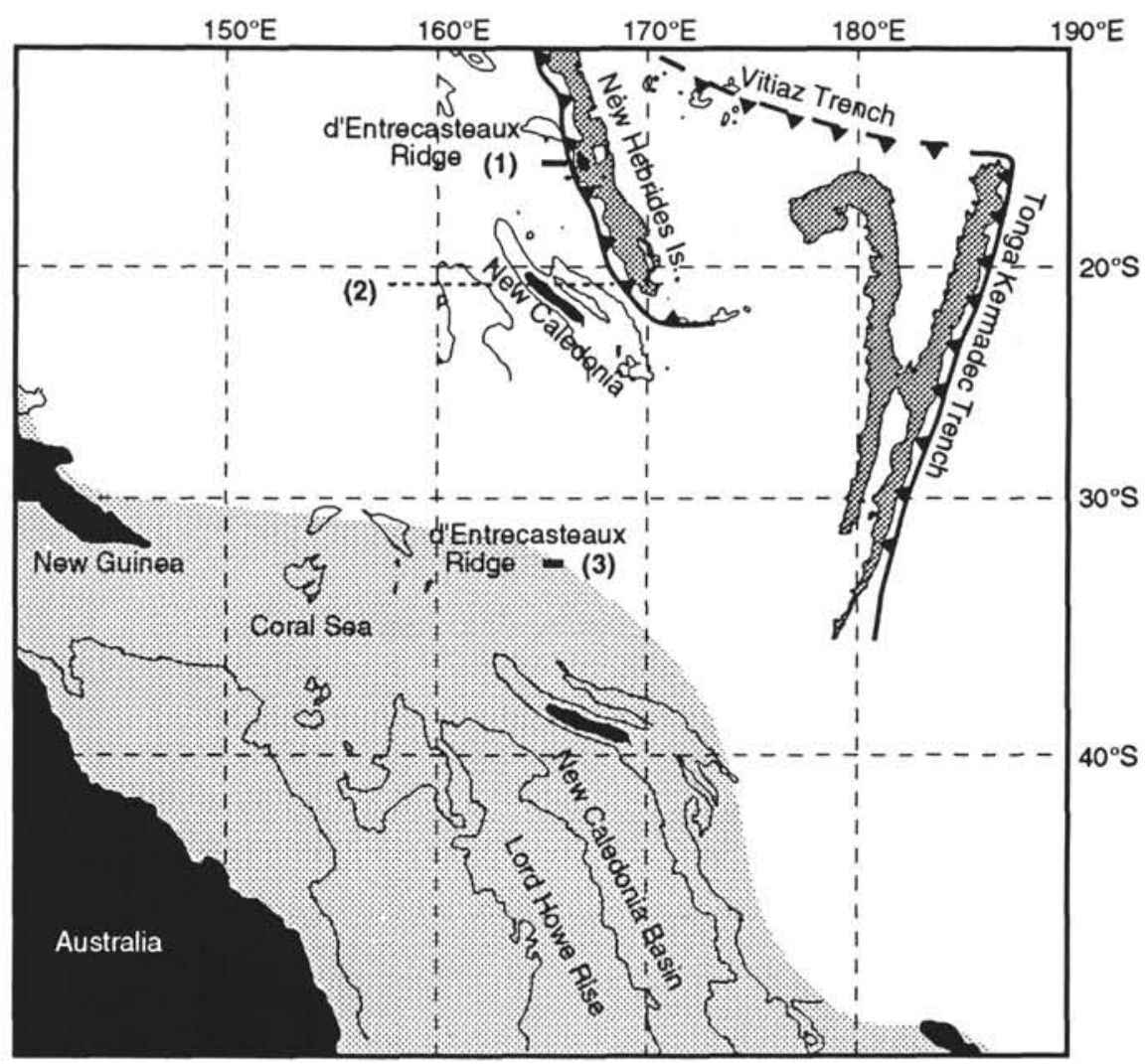

Figure 9. Paleogeographic map at $36 \mathrm{Ma}$ for the southwest Pacific in the hotspot reference frame model of Duncan and Richards (1991). The New Caledonia Basin, the Lord Howe Rise, and the Coral Sea have been attached to Australia since the late Eocene. Australia, New Caledonia, and the 2000-m bathymetric features have been rotated to the $36 \mathrm{Ma}$ paleoposition. The structural elements (New Hebrides Island Arc, Vitiaz and Tonga-Kermadec trenches) are also shown in the present-day situation to highlight the north-south motion that has brought the d'Entrecasteaux Zone to its present position. (1) = present-day situation of the d'Entrecasteaux Zone, $(2)=$ expected paleolatitude (indicated by the dashed line) based on the mean inclination in Oligocene sediment, $(3)=$ expected paleolatitude from the hotspot reference frame. 